\title{
Geo-Electrical and Borehole Investigation of Groundwater in Some Basalts on the South-Eastern Flank of Mount Cameroon, West Africa
}

\author{
Anatole E. Djieto Lordon ${ }^{*}$, Christopher M. Agyingi', Veronica E. Manga², Nenita N. Bukalo³, \\ Etienne T. Beka ${ }^{4}$ \\ ${ }^{1}$ Department of Geology, University of Buea, Buea, Cameroon \\ ${ }^{2}$ Department of Environmental Science, University of Buea, Buea, Cameroon \\ ${ }^{3}$ Department of Mining and Environmental Geology, University of Venda, Thohoyandou, South Africa \\ ${ }^{4}$ Hydrotech, Douala, Cameroon \\ Email: *alordon@yahoo.com
}

How to cite this paper: Djieto Lordon, A.E., Agyingi, C.M., Manga, V.E., Bukalo, N.N. and Beka, E.T. (2017) Geo-Electrical and Borehole Investigation of Groundwater in Some Basalts on the South-Eastern Flank of Mount Cameroon, West Africa. Journal of Water Resource and Protection, 9, 1526-1546.

https://doi.org/10.4236/jwarp.2017.912097

Received: September 30, 2017

Accepted: November 27, 2017

Published: November 30, 2017

Copyright $\odot 2017$ by authors and Scientific Research Publishing Inc. This work is licensed under the Creative Commons Attribution International License (CC BY 4.0).

http://creativecommons.org/licenses/by/4.0/

\section{(c) (i) Open Access}

\begin{abstract}
The study area, located on the southwestern flank of Mt. Cameroon, is underlain by basalts. The occurrence of groundwater in these rocks has been evaluated in order to determine their potentials as a source of water for a water bottling and soft drink plant. To achieve this, the constant separation traversing (CST) was used and the data qualitatively analyzed to determine the occurrence of fractures as most probable borehole sites. From this analysis, three sites were selected, sites at which a vertical electrical sounding (VES) was done and interpreted. Results obtained show a four layered earth profile model type $\mathrm{KHKH}$, corresponding to a typical weathered/fractured confined aquifer type curve. This profile was later confirmed from borehole information after drilling at three of the selected sites. The comparison of VES data with geological sections is corroborative. A constant rate pumping test was done at rates as well as the investigation of other hydraulic properties. The results obtained for hydraulic properties investigated for all three boreholes reveal that productivity is very good and these results also reveal that at maximum exploitation rates, lowest tolerable drawdown for all three boreholes may not be reached after ten years. Chemical analysis done in-situ and on samples at the laboratory reveal that this water has a better mineralisation compared to other bottled water brands sold on the Cameroon market.
\end{abstract}

\section{Keywords}

Aquifer, Constant Separation Traversing, Resistivity, 
Vertical Electrical Sounding

\section{Introduction}

Groundwater constitutes a very important natural resource for mankind. It occurs almost everywhere beneath the surface of the earth within saturated zones where the hydro-static pressure is equal to or greater than atmospheric pressure. Most of groundwater comes from precipitation and is stored in, and moves slowly through layers of soil, sand and rocks called aquifers, which may either be igneous, sedimentary or metamorphic. Despite the fact that Cameroon is endowed with abundant water resources, the quest for suitable and viable portable water sources remains a challenge for different water stakeholders. Thus as the need for portable water increases, great care should be taken to ensure sustainability of the water resources with respect to quantity and quality. Challenges of water resources exploitation combined with an increasing population, therefore, presents greater challenges to stakeholders at all levels [1] [2].

Mount Cameroon whose geographic occurrence is in Buea, in the South West region of Cameroon, is a $4095 \mathrm{~m}$ high and $50 \mathrm{~km}$ wide volcano along the Cameroon Volcanic Line. This mountain is predominantly made up of volcanic materials (basalts, lavas and pyroclastics) and containing several faults and fractures [3]. The coarse nature of the pyroclastics and the presence of fractured lavas make Mount Cameroon [4] potential volcanic aquifer system. The potential of volcanic rocks as aquifers strongly depends on their hydraulic characteristics, including the hydraulic conductivity, transmissivity and storativity. Hydraulic conductivity values range from orders of $10^{-8}$ (unfractured igneous and metamorphic rocks) to $10^{4}$ (lava flows and gravel). Transmissivity is the capacity of an aquifer to transmit water of the prevailing kinematic viscosity. It is the product of the hydraulic conductivity and the aquifer's thickness [5]. Determination of hydraulic characteristics of an aquifer could be done by carrying out geo-electric and borehole investigations. A combination of both geo-electrical and borehole investigations provide optimum information on hydraulic characteristics of an aquifer [6]. Pumping tests are the only borehole investigations that provide simultaneous information on the hydraulic behaviour of the well (borehole), the reservoir and the reservoir boundaries, which are essential for efficient aquifer and well field management [7]. Pumping tests areused for two purposes: 1) to determine the performance characteristics of a well and 2) to determine the hydraulic characteristics of an aquifer. A geo-electric investigation could involve both vertical electric sounding (VES) and constant separation traversing (CST). VES is used for depth sounding to determine the vertical variation of resistivity, while CST is used for horizontal variation of resistivity [8]. VES and CST allow an electrical image of the subsurface to be created that can be used to evaluate groundwater distribution in the aquifer [9]. These methods function as com- 
plementary tools, reduce uncertainties in subsurface exploration and assist in determining the most reliable location for groundwater exploitation [10].

Shortage of potable water for human consumption as well as industrial needs has grown and continues to grow across the country. The supply by the national water company in metropolis is grossly inadequate and most people depend on surface water and water from hand dug wells, while the most privileged are supplied by water from shallow or deep boreholes. While ground water is easily obtainable in sedimentary areas, the situation is more complex in bedrock areas. The location of possible aquifers in such areas could be possible through geo-electrical and borehole investigations. Currently in Cameroon, there is an observable increase in demand for bottled water as people believe such water may have a better level of purification than that provided by the local portable water providers. More so, bottled water can get to remote areas easily than establishing portable viable portable water schemes in such areas. The objective of this paper is to determine the potential of basalts in the study area as a source of water for a water bottling and soft drink plant, using geo-electrical and borehole investigations.

\section{Geologic Setting}

The study area is located at the south western flank of Mount Cameroon (Figure 1). The mountain consists of more than a hundred cones which originate from moderate explosive activity [11]. It is the only active volcano [12] of a $1600 \mathrm{~km}$ long series of volcanoes known as the Cameroon Volcanic Line (CVL).

The CVL is an alignment of Tertiary continental and oceanic volcanic massifs trending $30^{\circ} \mathrm{N}$ from Pagulu Island to Lake Chad [13]. It is made up of oceanic horsts, namely, Pagalu, Bioko, Sao Tome and Principe, and continental horsts, namely, Mounts Cameroon, Rumpi, Manenguba, Bamboutos, Mbam, and Oku [14]. The different rock types along the CVL are dominated by granites or syenites, and subordinate intermediate, basic and ultrabasic rocks [15]. The Mount Cameroon's eruptions are generally made up of both mafic and silisic lavas. Mafic lavas are associatedwith strombolian-styleexplosive activity along fissures [16] [17], which comprise basanites, alkali basalts, hawaiites and mugearites, and occasionally pahoehoe lavas; while the silicic lavas comprise benmoreites, trachytes, phonolites and/or rhyolites [15].

Structurally, three major tectonic axes trending northeast-southwest control the volcanic activity of the mountain: the Batoke axis $\left(030^{\circ}-040^{\circ}\right)$, the Debundscha axis $\left(060^{\circ}-070^{\circ}\right)$ and the Limbe axis $\left(140^{\circ}-150^{\circ}\right)$ [3] and [11]. The $060^{\circ}$ $070^{\circ}$ corresponds to a major Precambrian shear zone considered as the continuation of the Pernambuco lineament in northeast of Brazil, prior to the continental separation [18]. Two main faults oriented SSW-NNE are found around Mount: the Tiko fault to the East and the Boa fault to the West. [19] also identified the Likomba, Esuke, Ombéand Tole-Ekona faults on the East flank. According to [20], three factors control the availability of groundwater in the Mount Cameroon region: 1) the degree and depth of weathering of the volcanic rocks, 2) the 


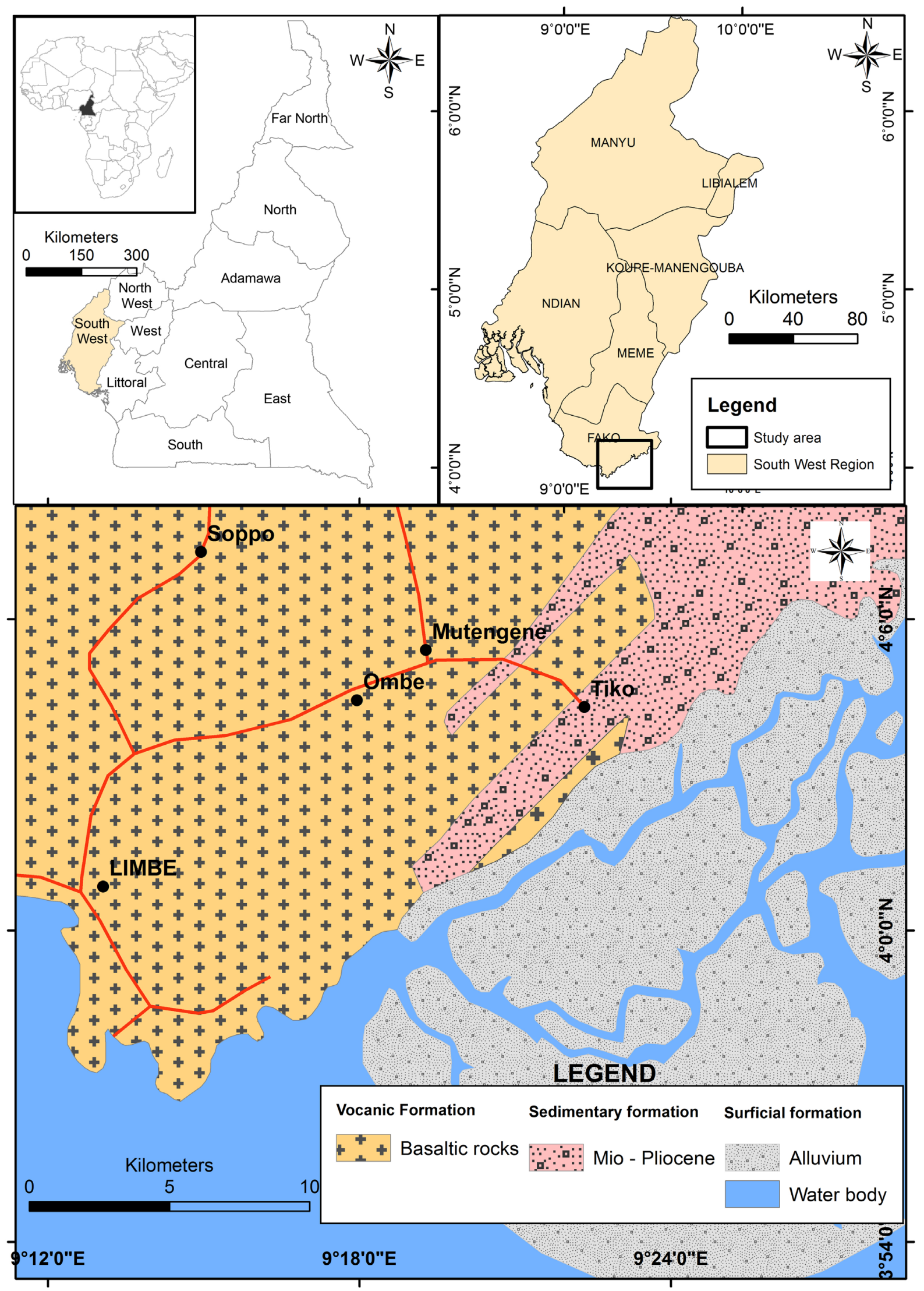

Figure 1. Geologic and locationmap of the study area. 
absence or presence of permeable surficial materials to allow infiltration into the subsurface, and 3) the presence or absence of faults, joints, fractures and other lineaments.

\section{Methods of Study}

\subsection{Resistivity Method}

The geophysical method adopted for this study is the resitivity survey in particular the Schlumberger configuration. The measurements are obtained by introducing a direct current into the ground through a pair of electric current electrodes ( $\mathrm{A}$ and $\mathrm{B}$ ) and measuring the resulting potential difference between the electrodes $\mathrm{M}$ and $\mathrm{N}$. For a homogeneous ground and an arbitrary electrode arrangement the resistivity can be calculated knowing the current I and the potential difference $d V$ between point $\mathrm{M}$ and $\mathrm{N}$ by the following equations as elaborated in [21].

\subsection{Resistivity from VES}

At the locations of the four gradient zones as per CST curve, four successive VES curves were recorded. Since the sites with low gradient are expected to be favorable for borehole construction, VES is supposed to reveal the variation of electrical resistivity with depth and in doing so, suggest the possible aquiferous layers and therefore targets for subsequent drilling operations. The apparent resistively values $\left(\rho_{a}\right)$ were plotted against the current electrodes separation $(\mathrm{AB} / 2)$ on log-log graph papers.

The vertical electrical soundings were later inverted i.e. quantitatively interpreted using IP2WINautomated inversion software [22]. This program was used to perform quantitative analysis and interpretation of the field curves. The models resulting from this inversion are illustrated on Figure 3 and Figure 4.

\subsubsection{Constant Separation Traversing (CST)}

In constant separation traversing, a fixed electrode spacing is chosen and the whole electrode array is moved along a line of traverse or grid after each measurement is made. The value of apparent resistivity is plotted, generally, at the geometric center of the electrode array. Maximum apparent resistivity anomalies are obtained by orienting the profiles perpendicular to the strike of the geologic structure. The results are presented as apparent resistivity profiles or apparent resistivity maps or both [21]. A 250 meters long profile was covered by 50 measurement points taken at 5 meter interval with a Schlumberger configuration array of $\mathrm{AB}=240 \mathrm{~m}$ and $\mathrm{MN}=10 \mathrm{~m}$ the apparent resistivity curve was plotted against the measurement points (Figure 2).

\subsubsection{The Vertical Electrical Sounding (VES)}

The vertical electrical sounding (VES) consists of a succession of apparent resistivity measurements made with an increasing electrode separation, while keeping the center of the configuration and its orientation fixed [23]. The variation in 


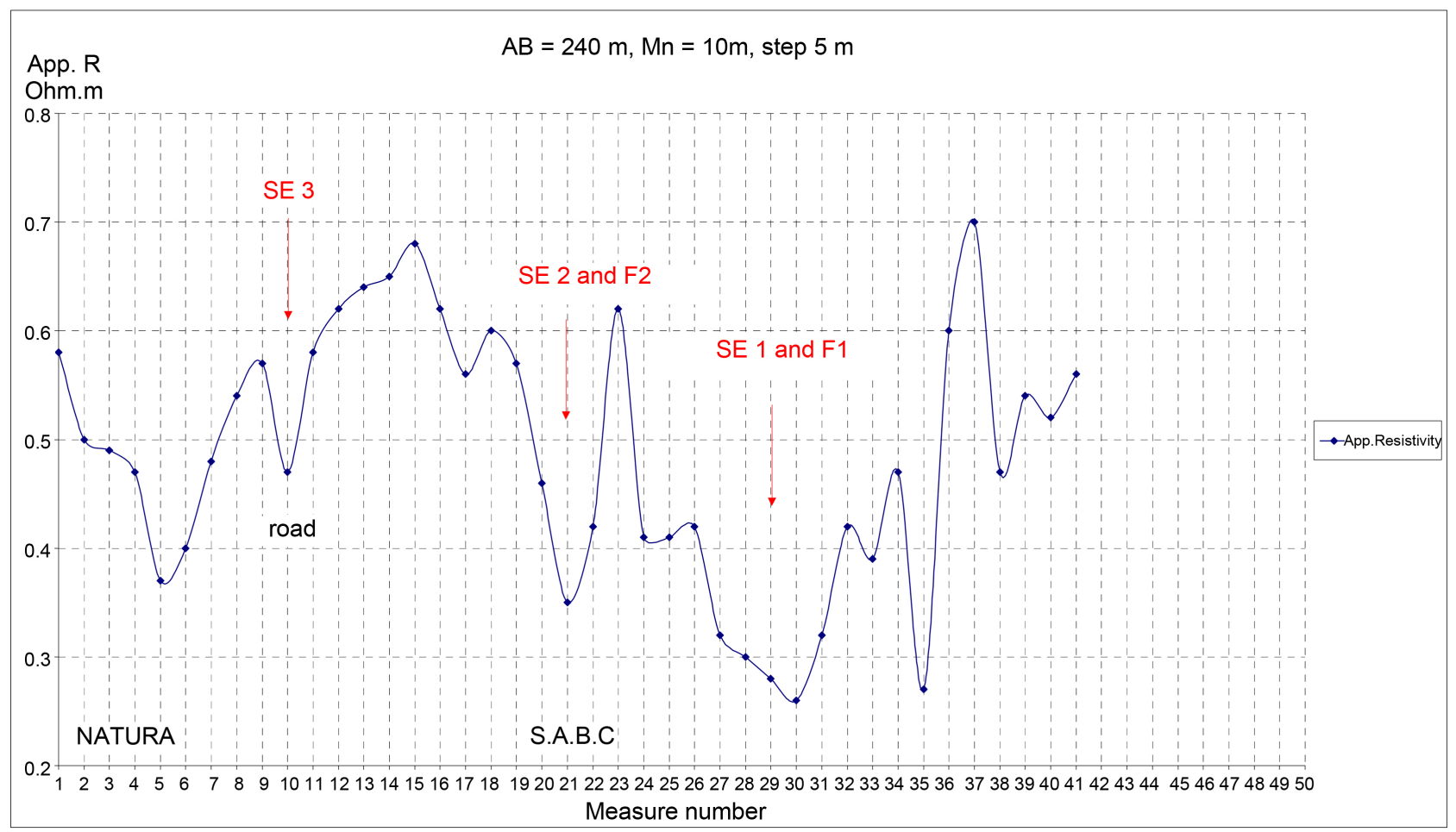

Figure 2. CST curve recorded along the profile presenting fractured zones identified as potential drilling sites.

apparent resistivity will essentially be due to the increasing depth of investigation. Practically, as the spacing between the current electrodes is increased about a center, the total volume of earth included in the measurement also increases both vertically and horizontally [23] [24]. The field procedure consists in measuring the apparent resistivity as the midpoint of the array is kept fixed while the distance between the current is progressively increased and plotting the apparent resistivity values against half the current electrode spacing on bilogarithmic graph paper. At the locations of the four gradient zones as per CST curve, four successive VES were recorded and plotted as VES 1-4, Figures 4(a)-(d). These data were acquired with ABEM Terrameter 1000 employing the VES and CST techniques of the Schlumberger configuration.

\subsection{Drilling}

At the positions corresponding to the high gradient zones as per CST curve, three boreholes (F1, F2 and F3) were drilled using rotary drilling techniques to depths indicated by the VES.

\subsection{Aquifer Tests}

Step-drawdown pumping tests and constant rate pumping tests [25] were carried out in the boreholes after the holes were equipped and developed. The step-drawdown pumping test was used to evaluate the performance of the well with regard to yield. This test (step-drawdown) was done in three boreholes (F1, F2 and F3) in three steps, with an interval of one hour and increasing pumping 
rates (Table 1 ).

The constant rate pumping test was done at pumping rates of $4.4 \mathrm{l} / \mathrm{s}$ for 24 hours at F1, 6.9 l/s for 48 hours at F2 and 11.1 1/s for 48 hours at F3. Drawdowns were taken manually using a water level indicator. These values were then used to determine the hydrodynamic parameters of the aquifer [7]. The goal of this test was to establish the reaction of the aquifer in case of high output and to determine the maximum discharge allowable. The water level was measured using a water level indicator. The results were analysed using the is-Jacob's method.

\subsection{Water Quality}

During the constant rate pumping test, water samples were collected and tested in-situ and the results compared with other bottled water brands. The $\mathrm{pH}$, conductivity, iron content and TDS were measured using HANNA Instruments.

\section{Results}

\subsection{Resistivity from CST}

The obtained values of apparent resistivity at each of the sampling points were plotted to generate the apparent resistivity curve along this profile as shown in Figure 3.

$$
\rho=\frac{K d V}{I} \text { with } K=2 \pi\left(\frac{1}{A M}-\frac{1}{B M}-\frac{1}{A N}+\frac{1}{B N}\right)^{-1}
$$

$K=$ geometrical factor for a symmetrical array with $\mathrm{O}$ middle of $A B$.

\subsection{Resistivity from VES}

At the locations of the four gradient zones as per CST curve, four successive VES were recorded. Since the sites with low gradient are expected to be favorable for borehole construction, VES is supposed to reveal the variation of electrical resistivity with depth and in doing so, suggest the possible aquiferous layers and therefore targets for subsequent drilling operations. The apparent resistively

Table 1. Duration and pumping rates of the step-drawdown pumping test carried out in the three boreholes.

\begin{tabular}{cccc}
\hline Boreholes & Steps & Duration & Pumping rates \\
\hline & S1 & 1 hour & $1.11 \mathrm{l} / \mathrm{s}$ \\
F1 & S2 & 1 hour & $2.22 \mathrm{l} / \mathrm{s}$ \\
& S3 & 1 hour & $3.89 \mathrm{l} / \mathrm{s}$ \\
& S1 & 1 hour & $5.56 \mathrm{l} / \mathrm{s}$ \\
F2 & S2 & 1 hour & $6.94 \mathrm{l} / \mathrm{s}$ \\
& S3 & 1 hour & $8.33 \mathrm{l} / \mathrm{s}$ \\
& S1 & 1 hour & $8.33 \mathrm{l} / \mathrm{s}$ \\
& S2 & 1 hour & $9.72 \mathrm{l} / \mathrm{s}$ \\
& S3 & 1 hour & $11.11 \mathrm{l} / \mathrm{s}$ \\
\hline
\end{tabular}


values $\left(\rho_{a}\right)$ were plotted against the current electrodes separation $(\mathrm{AB} / 2)$ on $\log$-log graph papers (Figure 3 and Figure 4). The vertical electrical soundings were later inverted using IP2WIN automated inversion software [22]. This program was used to perform quantitative analysis and interpretation of the field curves. The models resulting from these inversions are illustrated on Figure 3 and Figure 4.

\subsection{Lithology}

Three boreholes were drilled, including F1 $(40 \mathrm{~m}), \mathrm{F} 2(80 \mathrm{~m})$ and F3 $(110 \mathrm{~m})$. A lithology of the drilled boreholes is shown in Figure 5. A fourth borehole F4 is planned to be drilled on spot of the last major anomalous resistivity gradient of the CST curve. The proposed target is $130 \mathrm{~m}$ as per qualitative and quantitative interpretations and the expected lithologies from extrapolation from the previous borehole are summarized on Figure 5.

\subsection{Hydraulic Properties}

\subsubsection{Discharge and Specific Capacity}

The results of the step drawdown pumping tests carried out at the three boreholes are found in Table 2 . The productivity of F1 characterized by a specific discharge of $3.8 \mathrm{~m}^{3} / \mathrm{h} / \mathrm{m}$ for $14 \mathrm{~m}^{3} / \mathrm{h}$. This productivity was observed for one
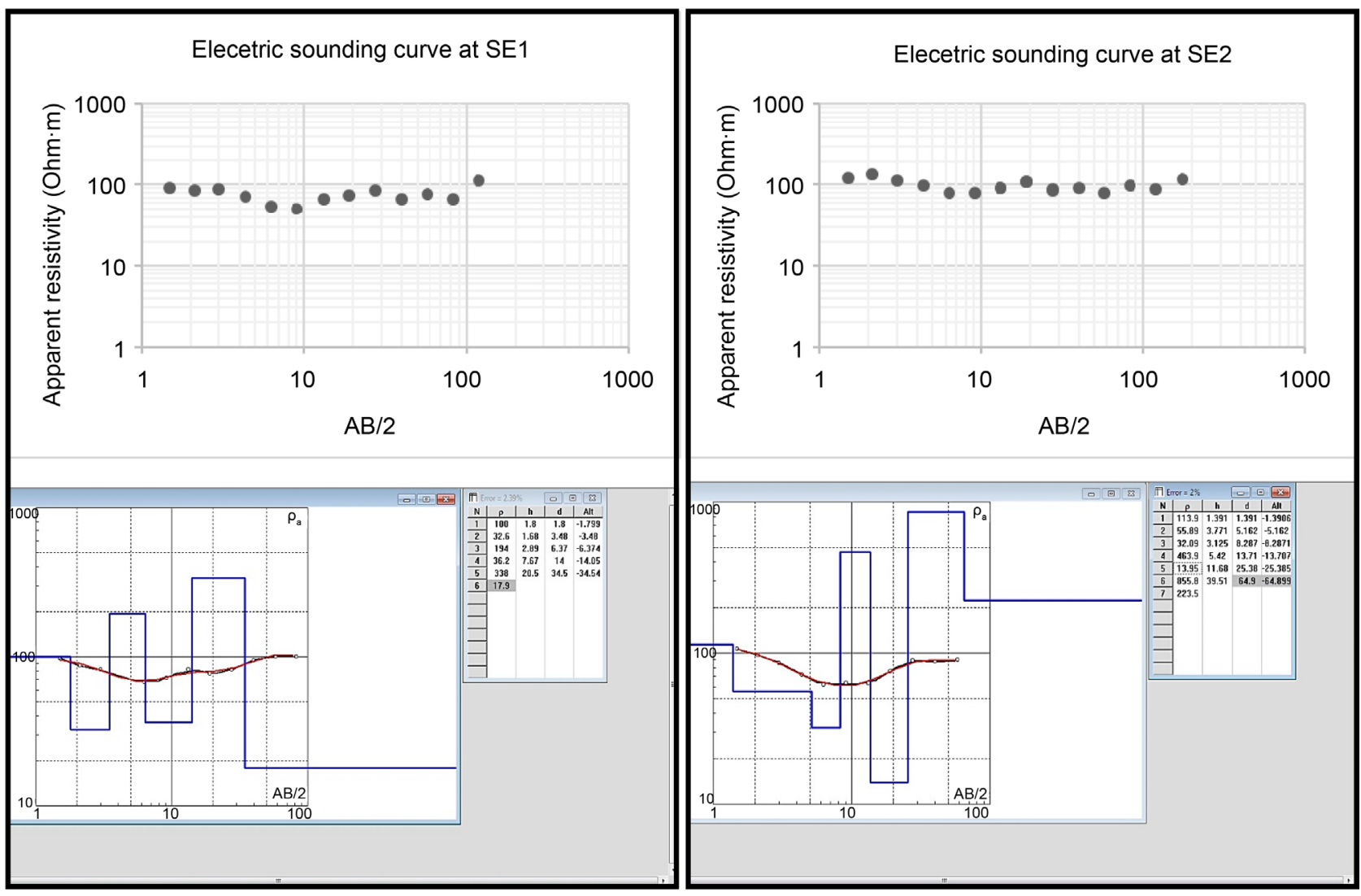

Figure 3. VES curves recorded at the locations of the first two gradient zones as per CST curve with the corresponding IP2W in models. 

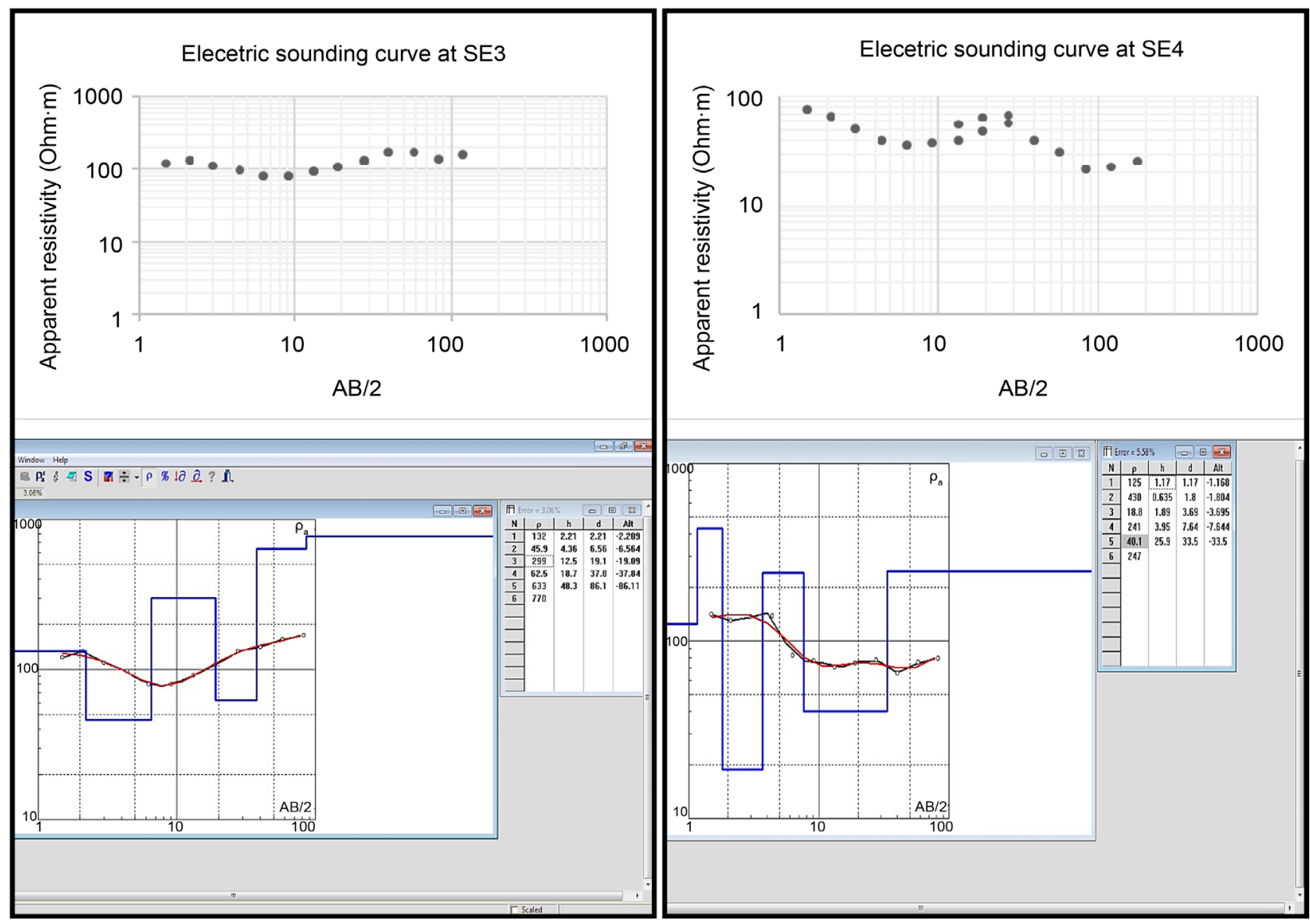

Figure 4. VES curves recorded at the locations of the last two gradient zones as per CST curve with the corresponding IP2Win models.

hour pumping duration. F2 has a specific discharge of $1.9 \mathrm{~m}^{3} / \mathrm{h} / \mathrm{m}$ while $\mathrm{F} 3$ has the highest specific capacity $\left(5.1 \mathrm{~m}^{3} / \mathrm{h} / \mathrm{m}\right)$ after one hour of pumping.

The plots of the drawdown versus the pumping rates for the 3 boreholes are shown in Figures 6-8.

The results of the three steps carried out on the three boreholes (F1, F2 and F3) fall on parabolas. The characteristic curve of F1 can be extrapolated to $10 \mathrm{l} / \mathrm{s}$ to obtain a drawdown of $10 \mathrm{~m}$ (Figure 6); the characteristic curve of F2 can be extrapolated to $10 \mathrm{l} / \mathrm{s}$ to obtain a drawdown of about $20 \mathrm{~m}$ (Figure 7), and the characteristic curve of F3 can be extrapolated to 20 1/s to obtain a drawdown of $27 \mathrm{~m}$ (Figure 8).

\subsubsection{Transmissivity and Hydraulic Conductivity from Constant Rate Pumping}

During the constant rate pumping test, the specific discharge equals $4.41 \mathrm{~m}^{3} / \mathrm{h} / \mathrm{m}$ after 24 hours pumping at a rate of $16 \mathrm{~m}^{3} / \mathrm{h}$. The drawdown stabilized at $4 \mathrm{~m}$. This productivity is also very good. The results of the constant rate pumping test carried in the three boreholes are shown in Table 3.

The recession and recovery curves of all three boreholes are shown in Figures 9-11. 


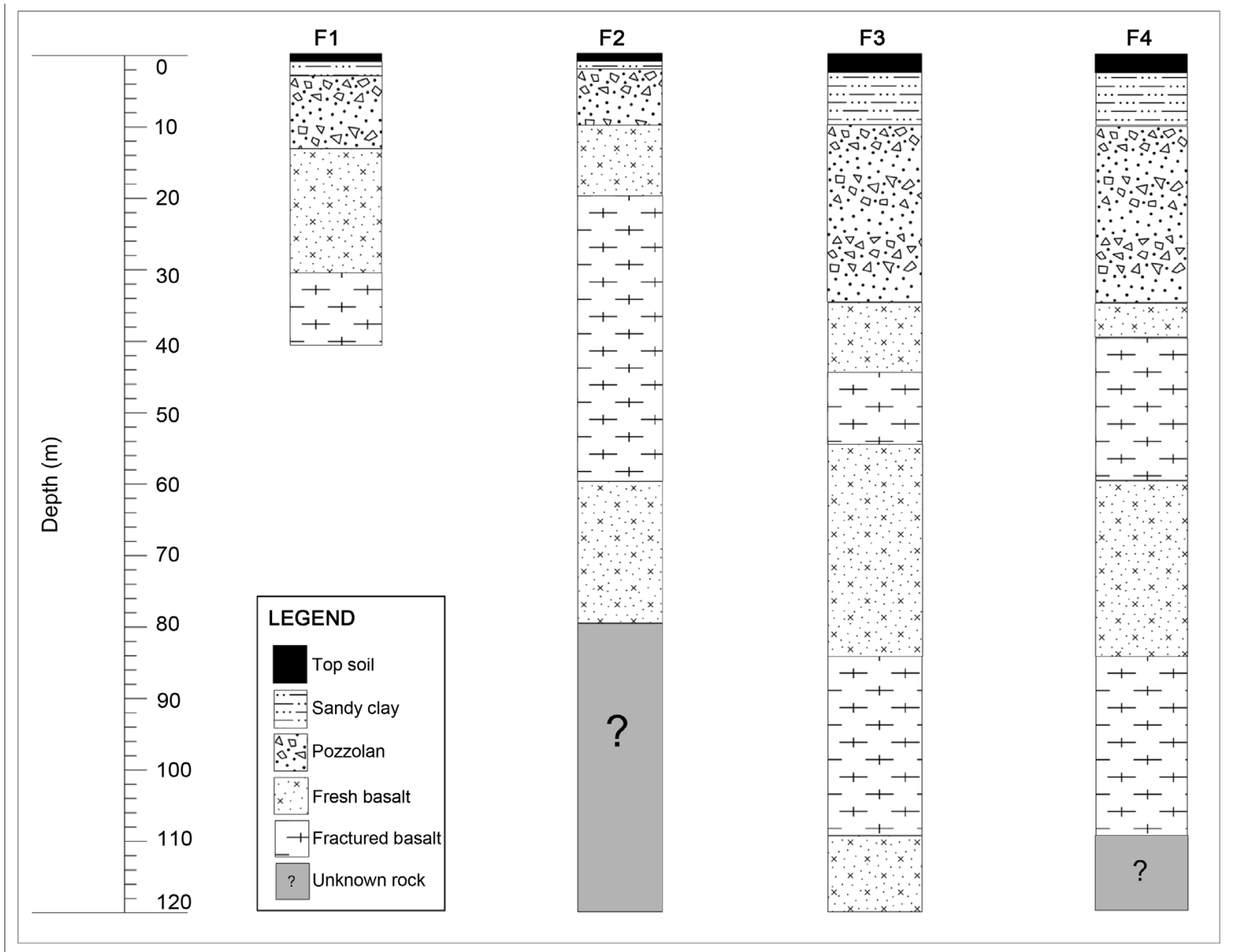

Figure 5. Lithologs of Ombe area.

Table 2. Results of the step-drawdown pumping test.

\begin{tabular}{|c|c|c|c|c|c|c|c|c|c|c|c|c|}
\hline & \multicolumn{3}{|c|}{$\mathrm{Q}(1 / \mathrm{s})$} & \multicolumn{3}{|c|}{ Drawdown (s) } & \multicolumn{3}{|c|}{$\begin{array}{l}\text { Specific capacity } \\
\mathrm{Q} / \mathrm{S}\left(\mathrm{m}^{3} / \mathrm{h} / \mathrm{m}\right)\end{array}$} & \multicolumn{3}{|c|}{$\begin{array}{l}\text { Specific drawdown } \\
\text { S/Q }\left(\mathrm{m} / \mathrm{m}^{3} / \mathrm{h}\right)\end{array}$} \\
\hline & $\mathrm{F} 1$ & $\mathrm{~F} 2$ & F3 & $\mathrm{F} 1$ & $\mathrm{~F} 2$ & F3 & $\mathrm{F} 1$ & $\mathrm{~F} 2$ & F3 & $\mathrm{F} 1$ & $\mathrm{~F} 2$ & F3 \\
\hline P1 & 1.11 & 5.56 & 8.33 & 1.12 & 10.95 & 5.84 & 3.57 & 1.83 & 5.14 & 0.28 & 0.55 & 0.19 \\
\hline $\mathrm{P} 2$ & 2.22 & 6.94 & 9.72 & 1.96 & 13.26 & 7.90 & 4.08 & 1.89 & 4.43 & 0.25 & 0.53 & 0.23 \\
\hline P3 & 3.89 & 8.33 & 11.11 & 3.69 & 15.65 & 9.53 & 3.79 & 1.92 & 4.20 & 0.26 & 0.52 & 0.24 \\
\hline
\end{tabular}

Table 3. Transmissivity and hydraulic conductivity from constant rate pumping test.

\begin{tabular}{ccccccccccc}
\hline & \multirow{2}{*}{ Discharge (1/s) } & \multicolumn{3}{c}{ Duration (hrs) } & \multicolumn{3}{c}{ Transmissivity $\left(\mathrm{m}^{2} / \mathrm{s}\right)$} & \multicolumn{3}{c}{ Hydraulicconductivity $(\mathrm{m} / \mathrm{s})$} \\
\cline { 3 - 10 } & & F1 & F2 & F3 & F1 & F2 & F3 & F1 & F2 & F3 \\
\hline P1 & 1.11 & 1 & 1 & 1 & $4.5 \times 10^{-4}$ & $5.4 \times 10^{-4}$ & $9 \times 10^{-4}$ & $2.41 \times 10^{-5}$ & $2.03 \times 10^{-5}$ & $1.57 \times 10^{-5}$ \\
P2 & 3.89 & 1 & 1 & 1 & $1.05 \times 10^{-3}$ & $2.7 \times 10^{-3}$ & $2 \times 10^{-3}$ & $5.42 \times 10^{-5}$ & $1.02 \times 10^{-5}$ & $3.56 \times 10^{-5}$ \\
PL & 4.44 & 2 & 48 & 48 & $8.1 \times 10^{-3}$ & $1.2 \times 10^{-3}$ & $9 \times 10^{-4}$ & $4.34 \times 10^{-5}$ & $4.58 \times 10^{-5}$ & $1.58 \times 10^{-5}$ \\
R & 0.00 & 1 & 2 & 2 & $8.7 \times 10^{-4}$ & $5.9 \times 10^{-4}$ & $8.6 \times 10^{-4}$ & $4.65 \times 10^{-5}$ & $2.24 \times 10^{-5}$ & $1.50 \times 10^{-5}$ \\
& & & & & $7.9 \times 10^{-4}$ & $6.3 \times 10^{-4}$ & $9.2 \times 10^{-4}$ & $4.22 \times 10^{-5}$ & $2.39 \times 10^{-5}$ & $1.61 \times 10^{-5}$ \\
\hline
\end{tabular}




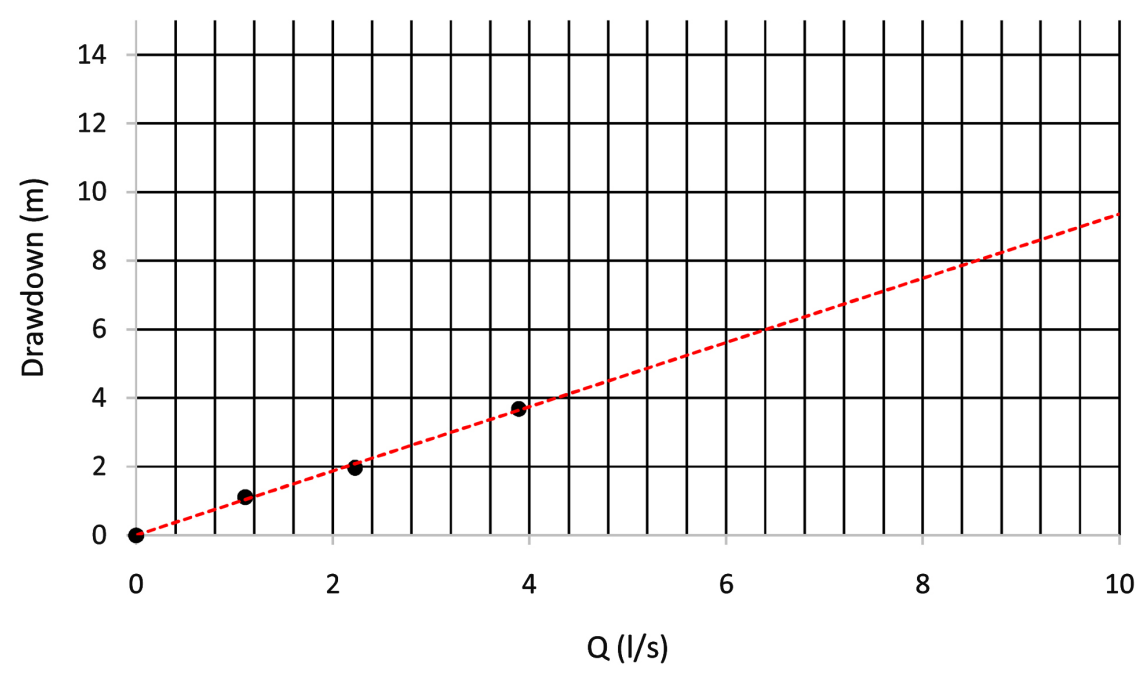

Figure 6. Characteristic curve of F1 (Drawdown vs pumping rate).

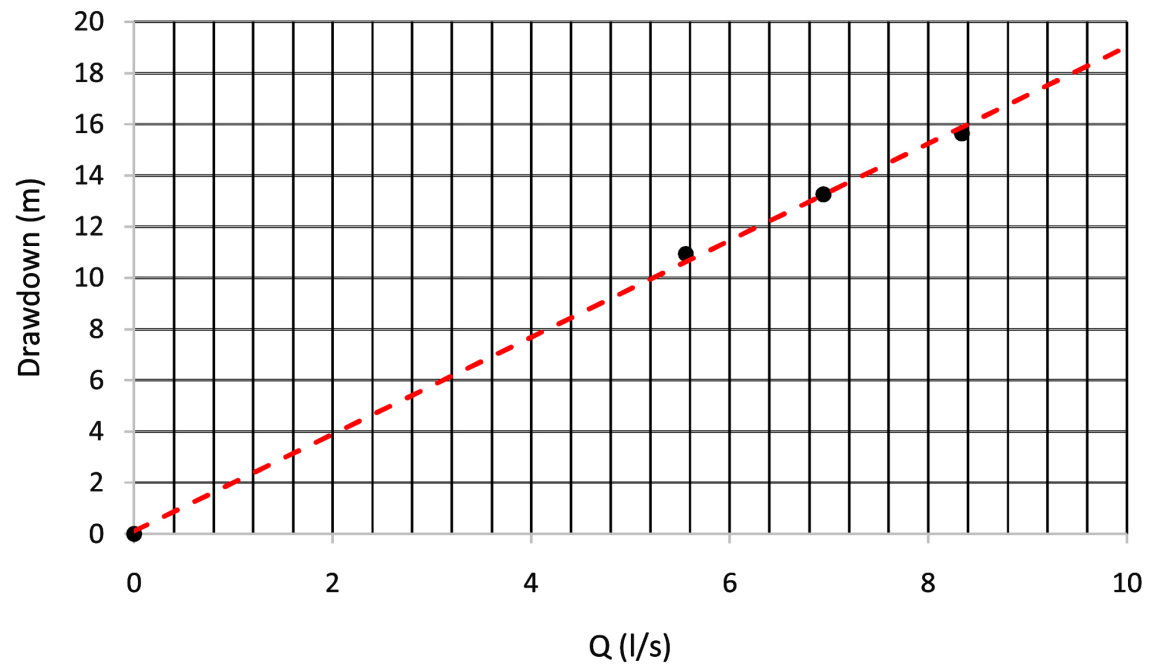

Figure 7. Characteristic curve of F2 (Drawdown vs pumping rate).

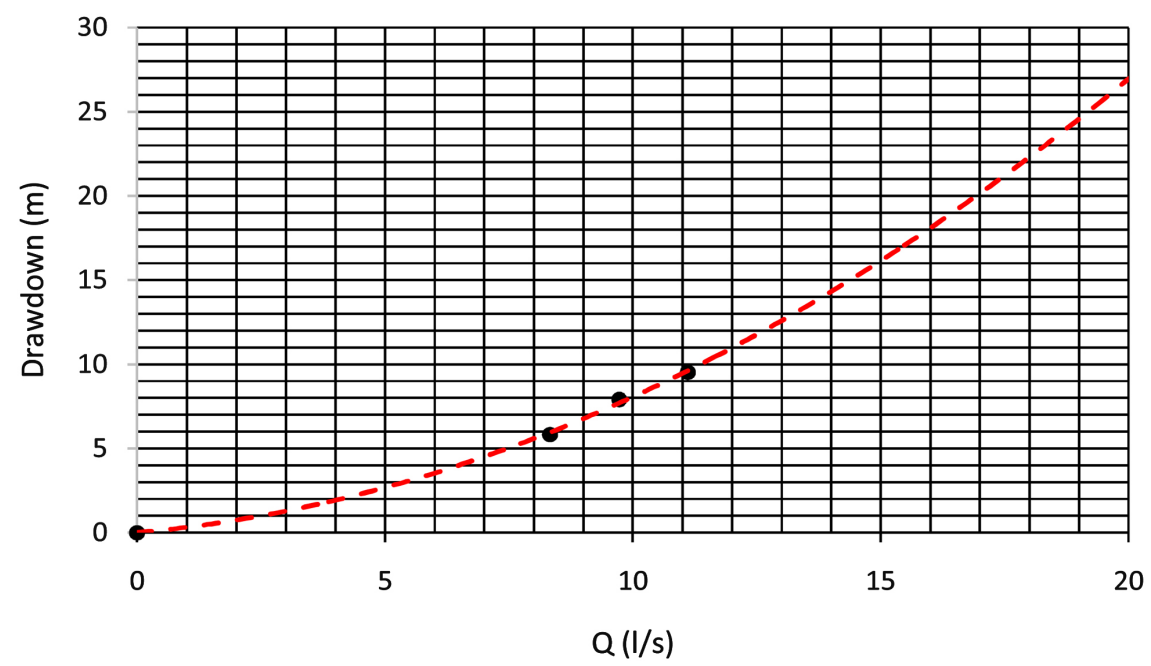

Figure 8. Characteristic curve of F3 (Drawdown vs pumping rate). 


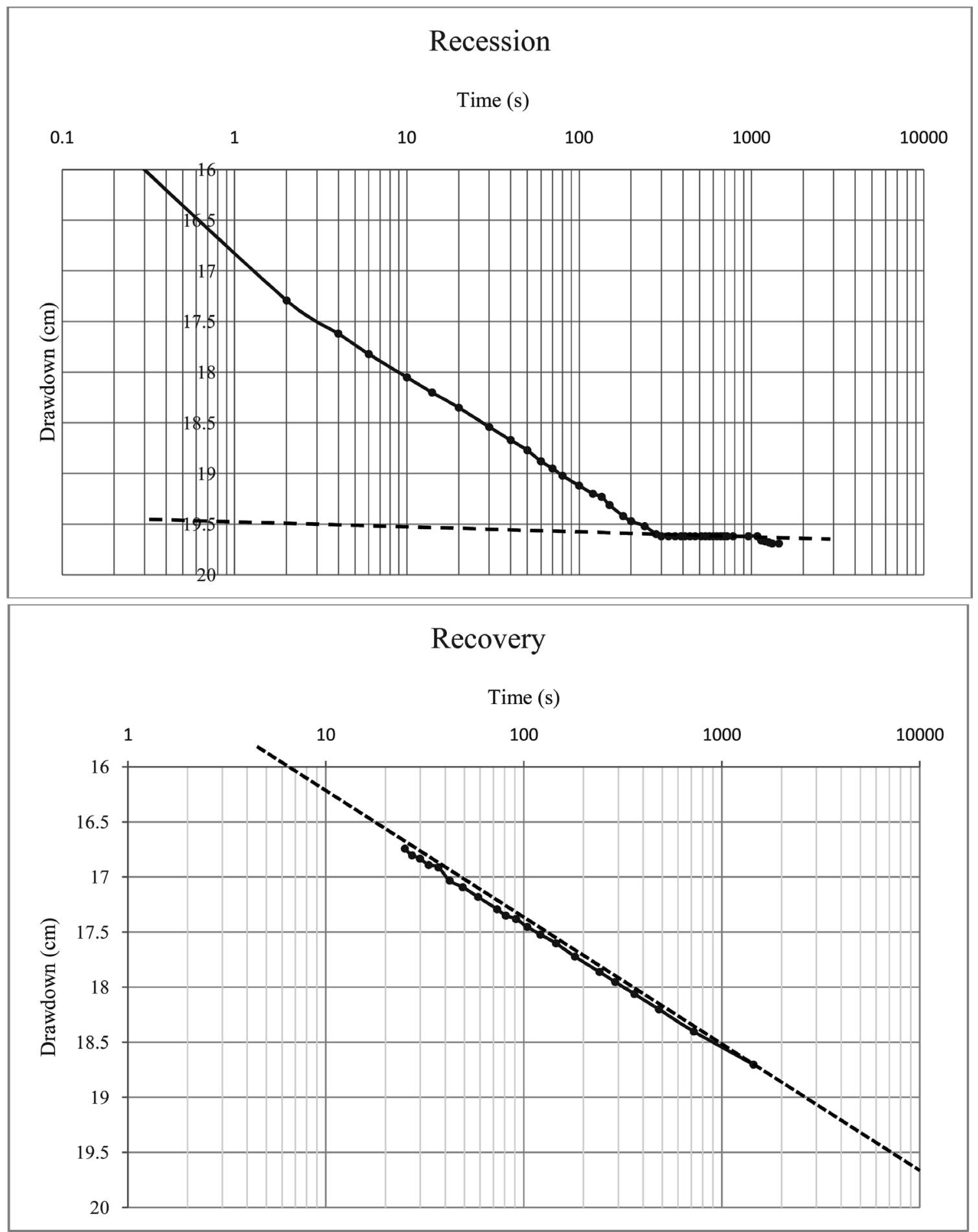

Figure 9. Recession and recovery curves of F1.

The maximum exploitation rates of the different boreholes obtained from a software simulation extrapolation after pumping the boreholes for a month, a year and ten years are found in Table 4. The lowest tolerable drawdown at F1 is $10 \mathrm{~m}$. This drawdown will not be attained after 10 years of exploitation at an average pumping rate of $4.0 \mathrm{l} / \mathrm{s}$. F2 can be exploited at an average pumping rate of 


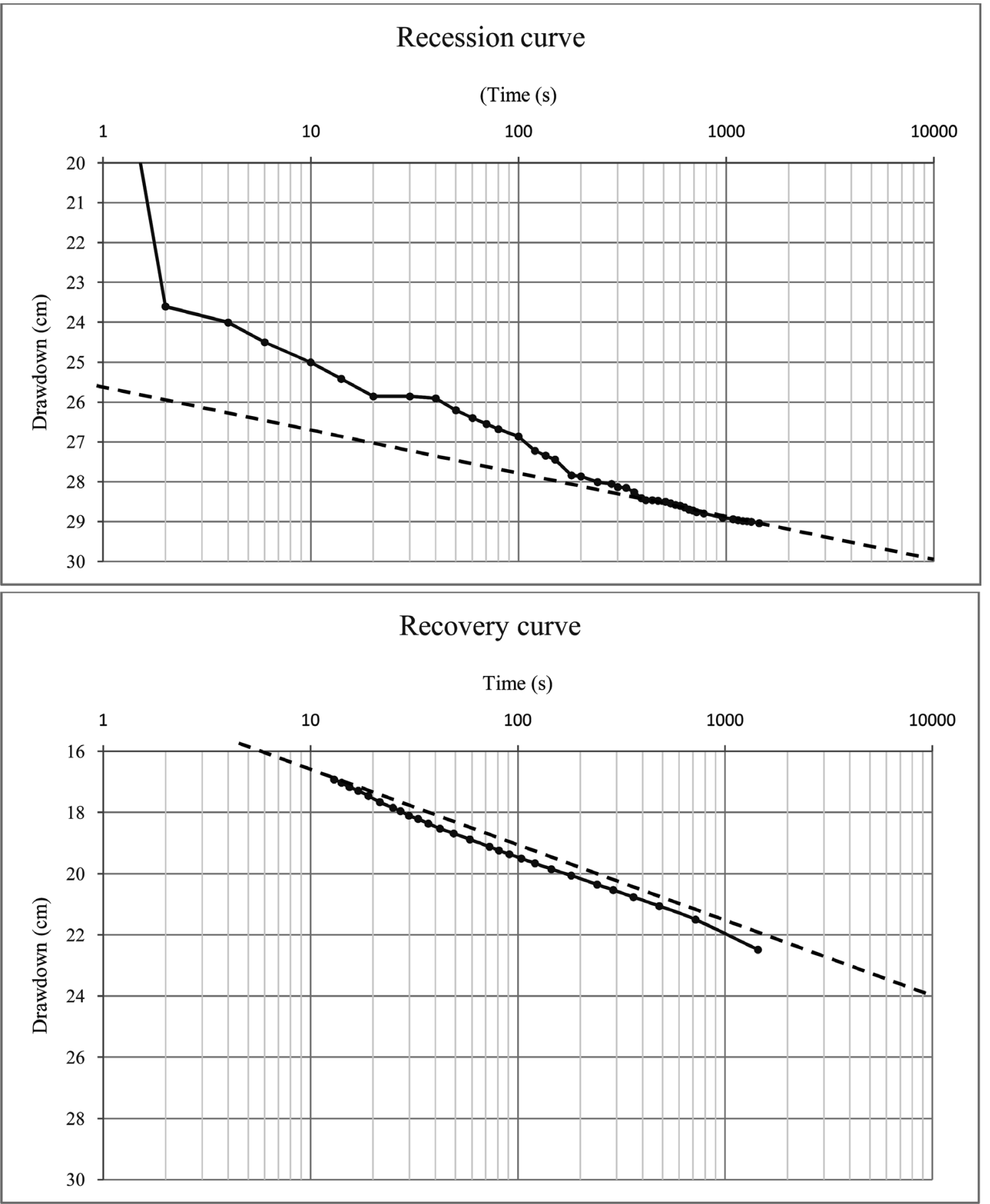

Figure 10. Recession and recovery curves of F2.

$5.9 \mathrm{l} / \mathrm{s}$, without the lowest tolerable drawdown at $22 \mathrm{~m}$ being attained after 10 years of exploitation. Similarly, the lowest tolerable drawdown of $43 \mathrm{~m}$ at F3 will not be attained after 10 years of exploitation at a pumping rate of $18 \mathrm{l} / \mathrm{s}$.

\subsubsection{Water Quality}

Chemical analysis of the water samples from the boreholes showed that bicarbonate is the most dominant anion $(231.8-268.4 \mathrm{mg} / \mathrm{l})$, whereas calcium is the 

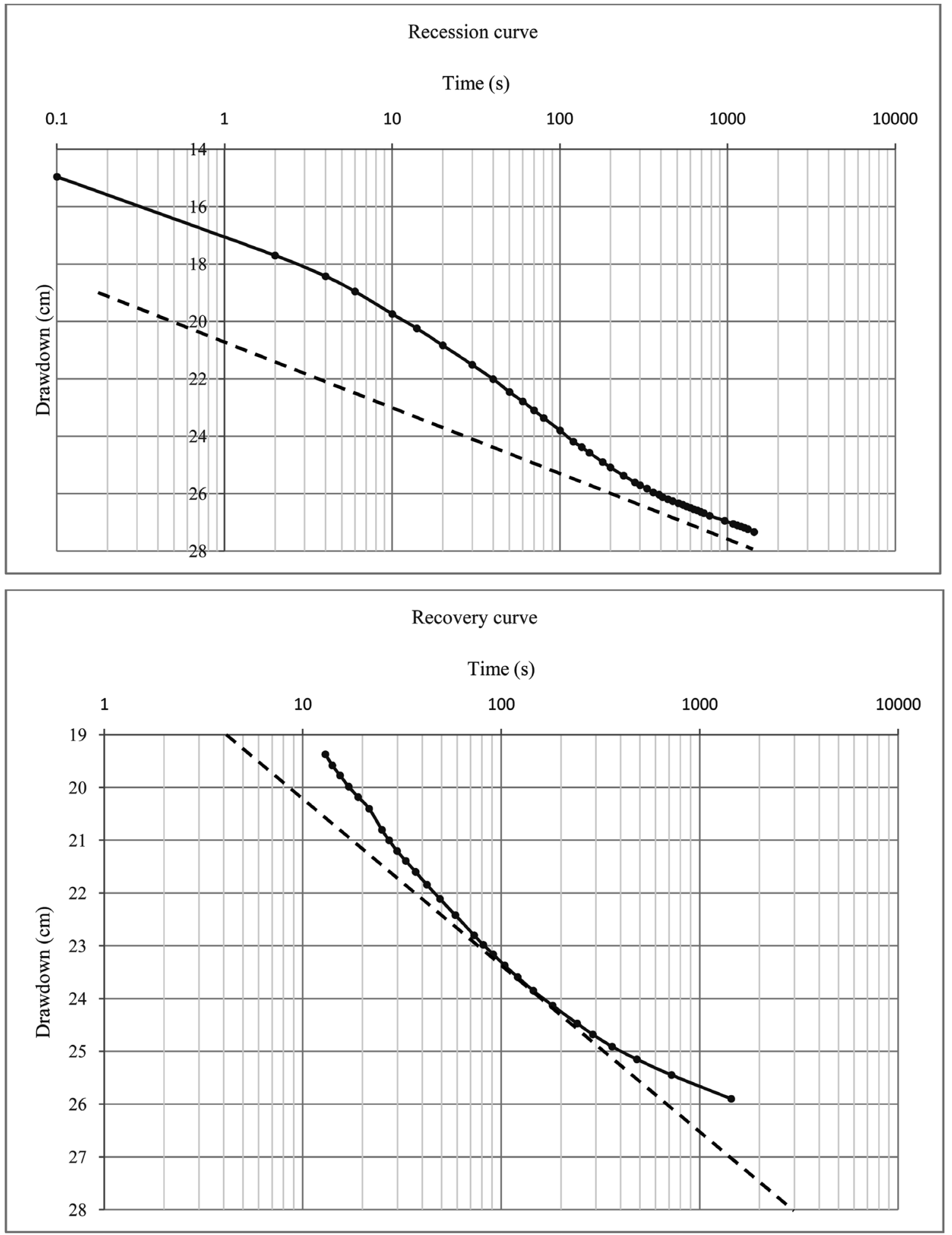

Figure 11. Recession and recovery curves of F3.

most dominant cation $\left(40-72 \mathrm{mg} / \mathrm{l}\right.$ ) (Table 5). $\mathrm{NO}_{3}^{-}$concentrations range between 0 (F2) and $1.98 \mathrm{mg} / \mathrm{l}(\mathrm{F} 1) . \mathrm{pH}$ ranges between $7.6(\mathrm{~F} 2)$ and $7.83(\mathrm{~F} 3)$, which is indicative of neutral waters; and EC values ranges 323 (F2) - $361 \mu \mathrm{S} / \mathrm{cm}$ (F1). 
Table 4. Maximum exploitation rates of the different boreholes.

\begin{tabular}{ccc}
\hline Borehole & Lowest tolerable drawdown $(\mathrm{m})$ & Maximum exploitation rates $(1 / \mathrm{s})$ \\
\hline F1 & 10 & 4.0 \\
F2 & 22 & 5.9 \\
F3 & 43 & 18 \\
\hline
\end{tabular}

Table 5. Selected chemical and physico-chemical parameters of the boreholes and WHO permissible limits.

\begin{tabular}{cccccccc}
\hline & $\begin{array}{c}\mathrm{Ca}^{2+} \\
(\mathrm{mg} / \mathrm{l})\end{array}$ & $\begin{array}{c}\mathrm{Mg}^{2+} \\
(\mathrm{mg} / \mathrm{l})\end{array}$ & $\begin{array}{c}\mathrm{HCO}_{3}^{-} \\
(\mathrm{mg} / \mathrm{l})\end{array}$ & $\begin{array}{c}\mathrm{Cl}^{-} \\
(\mathrm{mg} / \mathrm{l})\end{array}$ & $\begin{array}{c}\mathrm{NO}_{3}^{-} \\
(\mathrm{mg} / \mathrm{l})\end{array}$ & $\mathrm{pH}$ & $\begin{array}{c}\mathrm{EC} \\
(\mu \mathrm{S} / \mathrm{cm})\end{array}$ \\
\hline $\mathrm{F} 1$ & 72 & 43.2 & 268.4 & 1.91 & 1.98 & 7.69 & 361 \\
F2 & 72 & 43.2 & 231.8 & 0.7 & 0 & 7.6 & 323 \\
F3 & 40 & 24 & 253.76 & 2.12 & 0.14 & 7.83 & 334 \\
$\begin{array}{c}\text { WHO (2004) Highest } \\
\text { permissible limit }\end{array}$ & 50 & 150 & 600 & 200 & 45 & $7-9.5$ & - \\
\hline
\end{tabular}

A comparison was made between these samples and available water brands on the local market (Figure 12). The samples from the boreholes had better physico-chemical characteristics that those of local water brands (Alfa, Beta, Gamma and Delta). Water samples from these boreholes contain more than $60 \mathrm{mg} / \mathrm{lof}$ $\mathrm{Ca}^{2+}$, while the available water brands contain less than $50 \mathrm{mg} / \mathrm{l}$; the borehole water sample also contain more $\mathrm{Mg}^{2+}$ than all water brands. $\mathrm{pH}$ values are similar in all water samples; whereas EC varies considerably.

\section{Interpretation and Discussion}

\subsection{Structure and Aquiferous Zones}

The CST profile as shown in Figure 3 is characterized by a series of highs and lows with the highest peak value of $70 \mathrm{Ohm} \cdot \mathrm{m}$ and lowest value of $27 \mathrm{Ohm} \cdot \mathrm{m}$. The curve presents four major horizontal gradient zones with significant drop in the values of apparent resistivity. These gradient zones suggest an underlying fractured and/or weathered basement and these fractures are potential aquifers [26]. These results are good and in agreement with those obtained by [27] who used the same technique to decipher the existing subsurface stratification in the River Segen Dam Site in northern Ethiopia. Similar conclusions were reach by [28]. On the basis of the results obtained, points F1 $(5,37)$, F2 $(21,31)$, F3 (30, $26)$ and $\mathrm{F} 4(35,27)$ were selected as more probable site for further investigation by VES and potential sites for drilling.

\subsection{Resistivity of the Formations}

The four VES curves recorded at F1, F2, F3 and F4 are very similar in shape as well as in amplitude and all show a four-layered earth profile type $\mathrm{KHKH}$, corresponding to a typical conductive/resistive/conductive/resistive geoelectrical 


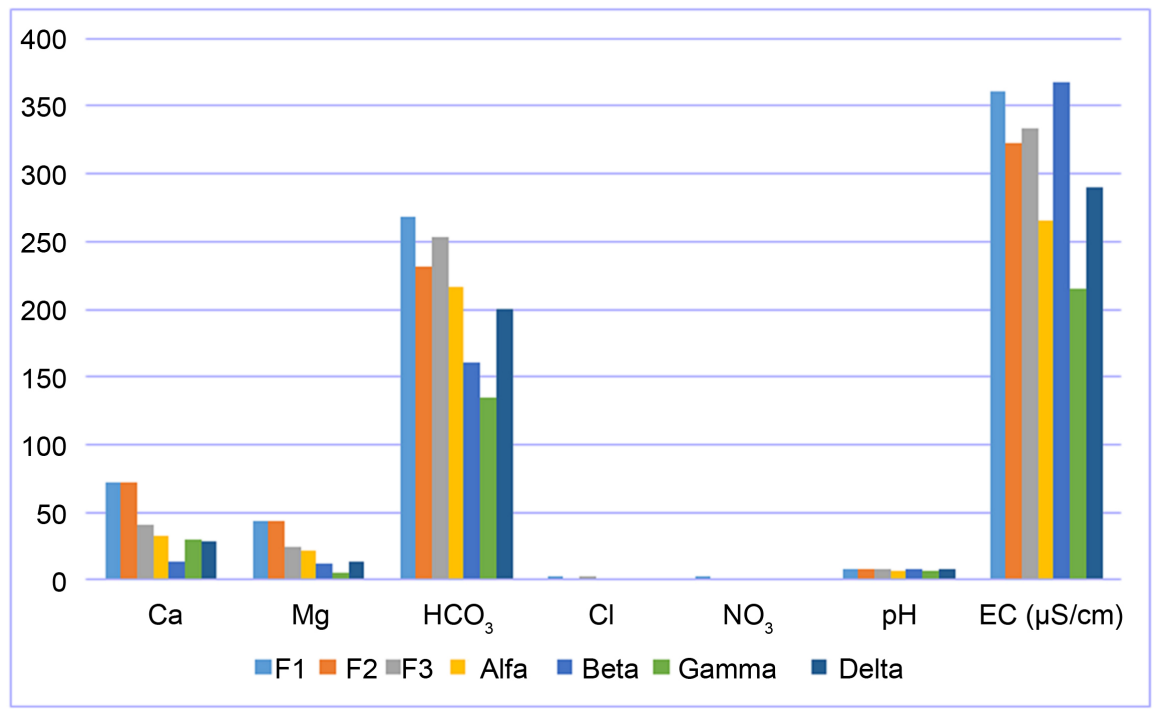

Figure 12. Comparison of the physico-chemical characteristics of the water samples in the boreholes and those of local brands.

section and implying that in addition to the presence of a top unconfined aquifer, there are two confined fractured zone within the fresh basement. The results of the four VES curves are summarized in Table 6.

The general shape of the different curves is indicative of a geological section made of resistive top soil, which becomes more conductive at around $5-6 \mathrm{~m}$ depth, with an apparent resistivity varying from 135 to $77 \mathrm{Ohm} \cdot \mathrm{m}$ approximately. This depth corresponds to the top of the clayey layer with basaltic boulders. This layer overlies a layer of relatively lower resistivity that extends to the depth of about $40 \mathrm{~m}$ and corresponds to a porous aquifer made up of fractured/altered basalts.

Beneath this layer is found a resistive bed of unfractured/unaltered basalt, extending from 40 to $55 / 60 \mathrm{~m}$. Another low resistivity layer, possible aquifer is detected around $80 \mathrm{~m}$ depth and extends to $120 \mathrm{~m}$ and corresponds to much fractured basalts. Below the depth of $120 \mathrm{~m}$, the bedrock is made of fresh unfractured basalt. It is worth noticing that all the VES curves reveal low variations of apparent resistivities ( 80 to $175 \mathrm{Ohm} \cdot \mathrm{m}$ ) up to $80 \mathrm{~m}$ depth. This corresponds to the interval of deposition of altered volcanic materials.

\subsection{Lithofacies and Aquiferous Formations}

The geological sections obtained from the processing of drilling data have been compared with the results of the vertical electrical sounding. From these comparisons, it appears that the interpretation of sounding curves corroborate the results obtained from the lithological sections made up of a top soil, sandy clay, fresh basalt, fractured basalt, fresh basalt and a last layer of fractured basalt. This means that the number and the order of occurrence of the aquifers match the drilling results. The only discrepancy is in the depths prediction from the VES data that do not match with the actual drilling depths. These discrepancies could 
Table 6. Results of the interpretation of the VES curves.

\begin{tabular}{ccccccccc}
\hline \multicolumn{2}{c}{ VES 1} & \multicolumn{2}{c}{ VES 2} & \multicolumn{2}{c}{ VES 3} & \multicolumn{2}{c}{ VES 4 } \\
\hline \multicolumn{2}{c}{ Thickness } & Resistivity & Thickness & Resistivity & Thickness & Resistivity & Thickness & Resistivity \\
\hline $0.1-3.0$ & $92.6-89.6$ & $0.1-3.0$ & $121-134.7$ & $1-2.1$ & $121-134.6$ & $0.1-3.0$ & $77.5-105.5$ \\
$3.0-9.1$ & $87.5-50.8$ & $3.0-9.1$ & $134.7-80.1$ & $2.1-6.3$ & $134.6-79.9$ & $3.0-9.1$ & $105.5-141.3$ \\
$9.1-27.5$ & $50.8-83.8$ & $9.1-19$ & $80.1-107.6$ & $6.3-9.1$ & $79.9-80.1$ & $9.1-27.5$ & $141.3-57.0$ \\
$27.5-83.0$ & $83.8-67.7$ & $19-58$ & $107.6-79.7$ & $9.1-40$ & $80.1-173.1$ & $27.5-40.0$ & $57.0-89.5$ \\
$83-120$ & $67.7-112.5$ & $58-83$ & $79.7-115.3$ & $40-83$ & $173.1-137.9$ & $40-58$ & $89.5-57.7$ \\
& & & & $83-120$ & $137.9-162.5$ & $58-120$ & $57.7-67$ \\
\hline
\end{tabular}

be explained by the suggestion that the weathered layer thickness includes partly weathered the semi weathered layer as well or the problem of equivalence. The identified aquifers from the different boreholes are shown in Table 7.

\subsection{Hydraulic Properties}

The different transmissivities obtained are less than the Deccan volcanic aquifer in India [29]. The same [29] obtained mean transmissivities of $3 \times 10^{-3} \mathrm{~m}^{2} / \mathrm{s}$ in the sheet joints of vesicular amygdaloidal basalt unit; $5 \times 10^{-4} \mathrm{~m}^{2} / \mathrm{s}$ in the vertical joints in compact basalt unit, and $2.2 \times 10^{-3} \mathrm{~m}^{2} / \mathrm{s}$ from boreholes crossing both sheet joints in vesicular amygdaloidal basalt and vertical joints in compact basalt. However, the hydraulic conductivities obtained fall in the ranges obtained by [30] in the Snake River Plain Aquifer, in Idaho (USA). Results obtained from [30] showed that most of the hydraulic conductivities of wells found in thin, tube-fedpahoehoe flows and near-vent volcanic deposits (shelly pahoehoe and slab pahoehoe flows and bedded scoria, spatter, and ash) range between $3.5 \times$ $10^{-6} \mathrm{~m} / \mathrm{s}$ and $3.5 \times 10^{-4} \mathrm{~m} / \mathrm{s}$.

\subsection{Groundwater Quality}

To an important extent, the chemical composition of mineral waters is determined by the composition of the rock it is abstracted from. Interactions between water and rock influence the mineral character of groundwater [31] by affecting its quality. The abundance of bicarbonate ions might be due to the fact that calcium carbonate occurs widely as secondary minerals in igneous rocks [32]. It is also possible that the high $\mathrm{HCO}_{3}^{-}$concentrations are related to $\mathrm{CO}_{2}$ degassing of Mount Cameroon [33]. There might have been a reaction between this $\mathrm{CO}_{2}$ and groundwater; leading to the formation of $\mathrm{HCO}_{3}$ or between biogenic and atmospheric $\mathrm{CO}_{2}$ and groundwater [34] [35] [36].

Potassium concentrations in volcanic rocks are usually low due to the resistance to weathering of potassium-bearing minerals and its fixation in the formation of clay minerals [37]. The study area also has distinct depletion in potassium [16]. Moreover, the lavas in this area form a basanite series with minerals such as clinopyroxenes (magnesium and/or iron rich), olivines (forsterite) and plagioclase (calcium rich). Therefore the principal cations in the area are calcium 
Table 7. Depths of different aquifers in the area.

\begin{tabular}{ccccc}
\hline Aquifers & Borehole F1 & Borehole F2 & Borehole F3 & $\begin{array}{c}\text { Borehole F4 } \\
\text { (expected) }\end{array}$ \\
\hline $1^{\text {st }}$ Aquifer & $3-13$ & $2-10$ & $10-35$ & $10-35$ \\
$2^{\text {nd }}$ Aquifer & $30-40$ & $20-60$ & $45-55$ & $40-60$ \\
$3^{\text {rd }}$ Aquifer & N/A & N/A & $85-110$ & $85-120$ \\
Estimated & & 100 & 120 & 130 \\
Depth (ED) & & & & \\
\hline
\end{tabular}

and magnesium ions. These cations are also found dominant in groundwater samples. Analysis of water samples from the three boreholes showed that their physico-chemical characteristics are within the [38] norms.

\section{Conclusion}

Geoelectrical survey was conducted on the southwestern flank of Mt. Cameroon, area underlain by basalts. The occurrence of groundwater in these rocks was order to determine their potentials as a source of water for a water bottling and soft drink plant. To achieve this, the constant separation traversing (CST) of the resistivity method was used and the data qualitatively analyzed to determine the occurrence of fractures as most probable borehole sites. As a result of this procedure, four sites were selected and at each of the preselected sites, a vertical electrical sounding (VES) was conducted and interpreted. The results of the interpretation of the VES data in the area showed a four layered earth profile model type $\mathrm{KHKH}$, corresponding to a typical weathered/fractured confined aquifer type curve. This profile was subsequently confirmed from borehole information after drilling at three of the four selected sites. A fourth borehole still to be drilled is expected to confirm the already obtained results. The comparison of results of VES curve interpretations with the geological sections obtained from boreholes curves is in good agreement. It shows that the number and the order of occurrence of the aquifers estimated from VES data match the drilling results. The only discrepancy is in the depths prediction from the VES data that do not match with the actual drilling depths, discrepancies that could be explained by the suggestion that the weathered layer from VES could include partly weathered the semi weathered layer as well. A Step-drawdown pumping test was done in three boreholes (F1, F2 and F3) in three steps, with an interval of an hour and increasing pumping rates. A constant rate pumping test was done at pumping rates of $4.4 \mathrm{l} / \mathrm{s}$ for 24 hours at F1, $6.9 \mathrm{l} / \mathrm{s}$ for 48 hours at F2 and 11.1 1/s for 48 hours at F3. The results of these tests were analysed using Theis-Jacob's method, and the transmissivity, hydraulic conductivity, the storage coefficient and the radius of influence were computed. These results reveal the existence of a high permeability zone around the three boreholes, with very good transmissivity that can safely produce water at a rate of $4.0 \mathrm{l} / \mathrm{s}, 5.9 \mathrm{l} / \mathrm{s}$ and $18 \mathrm{l} / \mathrm{s}$ for F1, F2 and F3, respectively, for a minimum of 10 years. Chemical analysis done in-situ 
during the pumping test and on samples at the laboratory reveal that this water has a lower iron content and better mineralisation compared with other bottled water brands sold on the Cameroon market.

\section{References}

[1] Teikeu, W.A., Njandjock, P.N., Ndougsa-Mbarga, T. and Tabod, T.C. (2012) Geoelectric Investigation for Groundwater Exploration in Yaounde Area, Cameroon. International Journal of Geosciences, 3, 640-649. https://doi.org/10.4236/ijg.2012.33064

[2] Akker, K. (2014) The Business of Water: Market Environmentalism in the Water Sector. Annual Review of Environment \& Resources, 39, 469-494.

https://doi.org/10.1146/annurev-environ-070312-132730

[3] Ateba, B., Dorbath, C., Dorbath, L., Ntepe, N., Frogneux, M., Aka, F.T., Hell, J.V., Delmond, J.C. and Manguelle, D. (2009) Eruptive and Earthquake Activities Related to the 2000 Eruption of Mount Cameroon Volcano (West Africa). Journal of Volcanology and Geothermal Research, 179, 206-216. https://doi.org/10.1016/j.jvolgeores.2008.11.021

[4] Ako, A.A., Jun, S., Takahiro, H., Makoto, K., Akoachere, R.A., George, E.N., Gloria, E.T.E. and Alain, L.F.T. (2012) Spring Water Quality and Usability in the Mount Cameroonarea Revealed by Hydrogeochemistry. Environmental Geochemistry and Health, 34, 615-639. https://doi.org/10.1007/s10653-012-9453-3

[5] Heath, R.C. (2004) Basic Groundwater Hydrology. 10th Edition, U.S. Geological Survey Water Supply Paper 2220, 91 p.

[6] Kosinski, W.K. and Kelly, W.E. (1981) Geoelectric Soundings for Predicting Aquifer Properties. Groundwater, 19, 163-171. https://doi.org/10.1111/j.1745-6584.1981.tb03455.x

[7] Poehls, D.J. and Smith, G.J. (2009) Encyclopedic Dictionary of Hydrogeology. Academic Press, San Diego, 527 p.

[8] Yeh, H.F., Lin, H.I., Wu, C.S, Hsu, K.C., Lee, J.W. and Lee, C.H. (2015) Electrical Resistivity Tomography Applied to Groundwater Aquifer at Downstream of Chih-Ben Creek Basin, Taiwan. Environmental Earth Sciences, 73, 4681-4687. https://doi.org/10.1007/s12665-014-3752-1

[9] Fields, J. and Halihan, T. (2015) Preliminary Electrical Resistivity Surveys of Mount Judea Alluvial Sites. 2nd Quarter 2015 Report. Boone Pickens School of Geology, Oklahoma State University, $24 \mathrm{p}$.

[10] Akinrinade, O.J. and Adesina, R.B. (2016) Hydrogeophysical Investigation of Groundwater Potential and Aquifer Vulnerability Prediction in Basement Complex Terrain-A Case Study from Akure, Southwestern Nigeria. De Gruyter Open. https://doi.org/10.1515/rmzmag-2016-0005

[11] Wandji, P., Tsafack, J.P.F., Bardintzeff, J.M., Nkouathio, D.G., Dongmo, A.K., Bellon, H. and Guillou, H. (2009) Xenoliths of Dunites, Wehrlites and Clinopyroxenites in the Basanites from Batoke Volcanic Cone (Mount Cameroon, Central Africa) Petrogenetic Implications. Mineralogy and Petrology. https://doi.org/10.1007/s00710-008-0040-3

[12] Njome, M.S., Suh, C.E. and de Wit, M.J. (2009) The Mount Cameroon Volcano, West Africa: An Active Link between Recent Eruptive and Mantle Signatures of the Deep Past beneath the Margins of Africa. 11th SAGA Biennial Technical Meeting and Exhibition, 533-539. 
[13] Kamgang, P., Chazot, G., Njonfang, E., Ngongang, N.B.T. and Tchoua, F.M. (2013) Mantle Sources and Magma Evolution beneath the Cameroon Volcanic Line: Geochemistry of Mafic Rocks from Bamenda Mountains (NW Cameroon). Gondwana Research, 24, 727-741. https://doi.org/10.1016/j.gr.2012.11.009

[14] Ngako, V. and Njongang, E. (2011) Plates Amalgamation and Plate Destruction, the Western Gondwanahistor. In: Closson, D., Ed., Tectonics, InTech, 370 p.

[15] Ngako, V., Njonfang, E., Aka, F.T., Affaton, P. and Nnange, J.M. (2006) The North-South Paleozoic to Quaternary Trend if Alkaline Magmatism from Niger-Nigeria to Cameroon: Complex Interaction between Hotspots and Precambrian Faults. Journal of African Earth Sciences, 45, 241-256.

https://doi.org/10.1016/j.jafrearsci.2006.03.003

[16] Suh, C.E., Sparks, R.S.J., Fitton, J.G., Ayonghe, S.N., Annen, C., Nana, R. and Luckman, A. (2003) The 1999 and 2000 Eruptions of Mount Cameroon: Eruption Behaviour and Petrochemistry of Lava. Bulletin of Volcanology, 65, 267-281. https://doi.org/10.1007/s00445-002-0257-7

[17] Ayonghe, S.N., Ntasin, E.B., Samalang, P. and Suh, C.E. (2004) The June 27, 2001 Landslide on Volcanic Cones in Limbe, Mount Cameroon, West Africa. Journal of African Earth Sciences, 39, 435-439. https://doi.org/10.1016/j.jafrearsci.2004.07.022

[18] Ngako, V., Affaton, P., Nnange, J.M. and Njako, T. (2003) Pan African Tectonic Evolution in Central and Southern Cameroon: Transpression and Transtension during Sinistral Shear Movements. Journal of AfricanEarth Science, 36, 207-214. https://doi.org/10.1016/S0899-5362(03)00023-X

[19] Zognig, A. (1989) The Mount Cameroon, an Active Volcano: Contribution to Applied Physical Geography Study. Unpublished Doctorate Thesis of the University of Yaounde, Yaounde, 447.

[20] Akoachere, R.A., Mbotake, I.T., Yaya, O.O. and Oteze, G.E. (2007) Using Morphometric Analysis to Evaluate Groundwater Hydraulic Characteristics in the Piedmont Regions of Mount Cameroon. 19th Annual Conference of Nigerian International Association of Hydrogeologists.

[21] Reynolds, J. (1998) An Introduction to Applied and Environmental Geophysics. John Wiley \& Sons Ed., New York.

[22] IP2WIN Program (2005) Programs Set for 1D VES Data Interpretation. Dept. of Geophysics, Geological Faculty, Moscow University.

[23] Telford, W.N., Geldart, L.P. and Shriff, R.E. (2001) Applied Geophysics. 2nd Edition, Cambridge, $770 \mathrm{p}$.

[24] Okweze, E.E., Selemo, A. and Ezeany, V.I. (1995) Preliminary Lithologic Deduction from Regional Electricalresistivity Survey of Ogoja, Nigeria. Nigerian Journal of Physics, 7, 43-46.

[25] Kawecki, M.W. (1995) Meaningful Interpretation of Step-Drawdown Tests. Ground Water, 33, 23-32. https://doi.org/10.1111/j.1745-6584.1995.tb00259.x

[26] Raimi, J., Abdulkarim, M.S., Hamidu, I. and Arabi, A.S. (2011) Application of Schlumberger Vertical Electrical Sounding for Determination of Suitable Sites for Construction of Boreholes for Irrigation Scheme within a Basement Complex. International Journal of Multidisciplinary Science and Engineering, 2, 81-84.

[27] Bairu, A. (2013) Application of Vertical Electrical Sounding and Horizontal Profiling Methods to Decipher the Existing Subsurface Stratification in River Segen Dam Site, Tigray, Northern Ethiopia. Journal of Environment and Earth Science, 3, 42-54. 
[28] Abraham, J.D. and Lucius, J.E. (2004) Direct Current Resistivity Profiling to Study Distribution of Water in the Unsaturated Zonenear the Amargosa Desert Research Site, Nevada. U.S. Geological Survey, Reston, Virginia 2004 Revised and Reprinted.

[29] Kulkrani, H., Deolankar, S.B., Lalwani, A., Joseph, B. and Pawar, S. (2000) Hydrogeological Framework of the Deccan Basalt Groundwater Systems, West-Central India. Hydrogeology Journal, 8, 368-378. https://doi.org/10.1007/s100400000079

[30] Anderson, S.R., Kuntz, M.A. and Davis, L.C. (1999) Geologic Controls of Hydraulic Conductivity in the Snake River Plain Aquifer at and near the Idaho National Engineering and Environmental Laboratory, Idaho. Water-Resources Investigations Report 99-4033, US Geological Survey, Idaho, 44 p.

[31] Edmunds, W.M., Shand, P., Hart, P. and Ward, R.S. (2003) The Natural (Baseline) Quality of Groundwater: A UK Pilot Study. The Science of the Total Environment, 310, 25-35. https://doi.org/10.1016/S0048-9697(02)00620-4

[32] Raymond, L.A. (2002) Petrology: The Study of Igneous, Sedimentary and Metamorphic Rocks. 2nd Edition, The McGraw-Hill Companies, New York, 720 p.

[33] Suh, C.E., Luhr, J.F. and Njome, M.S. (2008) Olivine-Hosted Glass Inclusions from Scoriae Erupted in 1954-2000 at Mount Cameroon Volcano, West Africa. Journal of Volcanology and Geothermal Research, 169, 1-33. https://doi.org/10.1016/j.jvolgeores.2007.07.004

[34] Jeong, C.H. (2001) Effects of Land Use and Urbanisation on Hydrochemistry and Contamination of Groundwater from Taejon Area, Korea. Journal of Hydrology, 253, 194-210. https://doi.org/10.1016/S0022-1694(01)00481-4

[35] Buccianti, A. and Pawlowsky-Glahn, V. (2005) New Perspectives on Water Chemistry and Compositional Data Analysis. Mathematical Geology, 37, 703-727. https://doi.org/10.1007/s11004-005-7376-6

[36] Olobaniyi, S.B. and Owoyemi, F.B. (2006) Characterization by Factor Analysis of the Chemical Facies of Groundwater in the Deltaic Plain Sands Aquifer of Warri, Western Niger Delta, Nigeria. African Journal of Science and Technology-Science and Engineering Series, 7, 73-81.

[37] Rajmohan, N. and Elango, L. (2006) Hydrogeochemistry and Its Relation to Groundwater Level Fluctuation in the Palar and Cheyyar River Basins, Southern India. Hydrological Processes, 20, 2415-2427. https://doi.org/10.1002/hyp.6052

[38] WHO (2004) Guidelines for Drinking-Water Quality. World Health Organization, Geneva. 